\title{
Implementasi Standar Pengelolaan Pendidikan Dalam Mencapai Tujuan Pendidikan Islam
}

\author{
1Palahudin; ${ }^{2}$ Muhammad Eri Hadiana; ${ }^{3}$ Hasan Basri \\ 1, 2,3Universitas Islam Negeri Sunan Gunung Djati Bandung, Indonesia \\ 1Palahudinblue@gamil.com; 2erihadiana@uinsgd.ac.id; 3hasanbasri@uinsgd.ac.id
}

\begin{abstract}
Islamic education is tasked with guiding and directing the development of students from one stage to another until it reaches optimal levels. Islamic education aims to create a perfect human (alinsanul kamil) and a good human being (al-insan al-shalih). Other tasks are in accordance with the vision and mission of the Prophet, namely perfecting human morals. A good education is certainly well managed. Therefore it is necessary to manage according to Islamic teachings. By using a qualitative descriptive research method, this study will try to dig deeper into the extent to which the achievement of education management standards in accordance with Islamic teachings and solutions to solve problems faced. The management of education in achieving the goals of Islamic education is education that is capable of making people who are faithful and devout, educating pious individuals by paying attention to spiritual, emotional, social, intellectual, physical development, educating members of pious social groups, both in the Muslim family and community.
\end{abstract}

Keywords. Education Management, Educational Objectives, Islamic Education.

Abstrak. Pendidikan Islam bertugas membimbing dan mengarahkan perkembangan peserta didik dari satu tahap ke tahap yang lain sampai mencapai optimal. Pendidikan Islam bertujuan untuk mewujudkan manusia yang sempurna (al-insanul kamil) dan manusia yang baik (al-insan al-shalih). Tugas lainnya sesuai dengan visi misi Rasulullah di utus, yakni menyempurnakan akhlak manusia. Pendidikan yang baik tentu dikelola dengan baik. Maka dari itu perlu dilakukan pengelolaan sesuai ajaran Islam. Dengan menggunakan metode penelitian Deskriptif Kualitatif, penelitian ini akan mencoba menggali lebih dalam mengenai sejauhmana pencapaian standar pengelolaan pendidikan yang sesuai dengan ajaran Islam serta solusi pemecahan masalah yang dihadapi. Pengelolaan pendidikan dalam mencapai tujuan pendidikan Islam adalah pendidikan yang mampu menjadikan manusia yang beriman dan bertaqwa, mendidik individu yang saleh dengan memperhatikan perkembangan rohaniah, emosional, sosial, intelektual, fisik, mendidik anggota kelompok sosial yang saleh, baik dalam keluarga maupun masyarakat muslim.

Kata Kunci. Pengelolaan Pendidikan, Tujuan Pendidikan, Pendidikan Islam.

Copyright (C J-PAI: Jurnal Pendidikan Agama Islam. All Right Reserved.

This is an open-access article under the CC BY-SA license

(https://creativecommons.org/licenses/by-sa/4.0/).

Correspondence Address: jpai@uin-malang.ac.id 


\section{A. PENDAHULUAN}

Pendidikan hakikatnya merupakan usaha yang direncanakan untuk terlaksananya pembelajaran dengan baik dan berkualitas (Widoyoko, 2009). Dengan tujuan agar peserta didik mampu mengembangkan potensi dirinya dalam hal spiritual keagamaan, pengendalian diri, kepribadian, kecerdasan, ahklak mulia, serta keterampilan yang diperlukan oleh manusia atau peserta didik (Rohman, 2019). Salah satu aspek penting dalam mencapai tujuan pendidikan yaitu pengelolaan pendidikan yang baik. Pengelolaan pendidikan dalam satuan pendidikan diserahkan kepada sekolah (Hidayat \& Machali, 2012). Kepala sekolah yang mengelola sesuai aturan idelanya pengelolaan pendidikan semakin baik.

Pembagian tugas kerja harus dilakukan oleh kepala sekolah untuk meningkatkan produktifitas pendidikan (Maqfirah, 2013). Pemimpin itu harus mampu mempengaruhi, mendorong mengajak untuk mencapai tujuan yang diharapkan (Nurhayati, 2016). Tujuan pengelolaan pendidikan adalah untuk mencapai sesuatu hal yang telah ditetapkan sebagai tujuan pendidikan baik secara institusi ataupun nasional. Pengelolaan merupakan komponen yang sangat penting dan tidak dapat dipisahkan dari proses pendidikan secara keseluruhan. Tanpa pengelolaan yang baik tidak mungkin mencapai tujuan pendidikan secara optimal, efektif, dan efisien (Anwar, 2017).

Standar Nasional Pendidikan terdiri dari perencanaan, pelaksanaan, dan pengawasan dengan tujuan agar tercapainya efisiensi dan efektivitas pendidikan (MUTIA, 2019). Harris dan Spillane (2008) mengemukakan bahwa pengelolaan sekolah membutuhkan adanya kolaborasi, jaringan kerjasama dan peran dari berbagai pihak yang dibutuhkan untuk membuat pola kepemimpinan yang didistribusikan dengan baik (Rahayu, 2015). Diperlukan sinerginya semua pihak untuk melakukan perubahan (Jannah, 2020). Kepala sekolah beserta jajarannya agar tetap ada komitmen melakukan perubahan, inovasi dan perbaikan. Kepala sekolah harus dapat mendesain struktur organisasi, dan membangun budaya organisasi yang terbuka, tumbuh dan berani ambil resiko (Rahayu, 2015).

Pendidikan Islam mempunyai definisi membimbing dan mengarahkan pertumbuhan dan perkembangan peserta didik dari tahap ke tahap sampai tahap optimal. Secara garis besarnya pengertian itu mencakup tiga aspek, yaitu: (1) Seperangkat teknik atau cara untuk memberikan pengetahuan, keterampilan dan tingkah laku. (2) Seperangkat teori yang maksudnya untuk menjelaskan dan membenarkan penggunaan teknik dan caracara tersebut. (3) seperangkat nilai, gagasan atau cita-cita sebagai tujuan yang menjelmakan serta dinyatakan dalam pengetahuan, keterampilan dan tingkah laku, termasuk jumlah dan pola latihan yang harus diberikan (Trinurmi, 2015).

Imam Al-Gazali mengemukanan bahwa pada dasarnya dua tujuan pokok pendidikan Islam yaitu untuk mencapai kesempurnaan dalam beribadah dan untuk mencapai kesempurnaan dunia akhirat. Sayyid Qutb menyatakan tujuan pendidikan adalah untuk mewujudkan manusia yang baik (al-insan al-salih) yang bersifat universal. Pada intinya pendidikan itu juga untuk menyempurnakan akhlak manusia (Trinurmi, 2015). Pada intinya perencanaan, pelaksanaan, pengorganisasian dan evaluasi pengelolaan pendidikan yang baik, akan mampu mencapai tujuan pendidikan Islam yang diharapkan sesuai AlQur'an dan As-Sunnah (Ikhwan, 2016). Dan tentunya harus dilakukan oleh ahli dibidangya dan professional. 


\section{B. METODE}

Penelitian ini menggunakan metode penelitian Deskriptif Kualitatif yang berarti mendeskripsikan data disertai gambaran maupun penafsiran serta menganalisis Standar Pengelolaan pendidikan. Analisis bisa diartikan sebagai penjelasan lebih rinci mengenai focus penelitian atau komponen-komponen yang diteliti (Wardani, Loekmono, \& Supramono, 2017). Penelitian deskriptif berusaha menjelaskan gejala, peristiwa, kejadian sesuai fakta (Soendari, 2012). Sampel yang diambil adalah 10 orang guru di SMP Negeri di Kota Bandung.

Instrumen yang digunakan adalah angket dan observasi. Angket merupakan daftar pertanyaan mengenai standar pengelolaan pendidikan sebanyak 15 indikator. Setiap responden mengisi jawaban dengan memilih salah satu jawaban yang dianggap sesuai dengan keadaan responden. Sedangkan wawancara digunakan untuk memperkuat data hasil angket. Teknik yang dilakukan yaitu dengan menanyakan langsung mengenai kendala dan alternative solusi kepada setiap responden. Melalui teknik ini diharapkan data yang diperoleh benar-benar lebih obyektif dan otentik. Subyek yang diwawancara yaitu responden yang memiliki skor pemahaman terhadap indiaktor yang rendah.

Langkah-langkah analisis data dilakukan dengan cara merekapitulasi skor, memberikan prosentase dan menyajikannya dalam bentuk grafik dan diagram. Analisis datanya yaitu dengan mencari jumlah nilai yang diperoleh setiap responden, rata-rata setiap responden, serta prosentase responden. Analisis yang lainnya yaitu analisis setiap standar pengelolaan dengan melihat jumlah perstandar, rata-rata perstandar dan prosentase perstandar. Untuk mendalami kendala yang dialami oleh responden, maka dilakukan triangulasi dan disajikan sehingga diperoleh alternative solusi untuk meningkatkan pemahaman guru terhadap standaar pengelolaan pendidikan untuk mencapai tujuan pendidikan Nasional.

Selanjutnya hasil yang diperoleh dihubungkan dengan pengelolaan pendidikan Islam serta dihubungkan dengan tujuan pendidikan Islam. Dari data tersebut pula dilakukan analisis ketercapaian sesuai dengan pengelolaan pendidikan Islam, serta mencari alternative solusi versi pendidikan Islam dari berbagai sumber dan para ahli pendidikan Islam.

\section{HASIL DAN PEMBAHASAN PENELITIAN}

\section{Perolehan Data Pemahaman Standar Pengelolaan Pendidikan}

Setelah dilakukan penyebaran angket mengenai pemahaman standar pengelolaan pendidikan di salah satu SMP Negeri Kota Bandung. Diperoleh hasil yang bervariatif sesuai pemahaman guru yang diberi angket. Dalam angket dipetakan mengenai perencanaan, pelaksanaan dan evaluasi mengenai standar pengelolaan pendidikan dalam bentuk 15 standar pengelolaan pendidikan.

Instrument penelitian tentang standar pengelolaan pendidikan mengacu kepada Perangkat Akreditasi SMP-MTs 2017 (Sekolah, n.d.) dengan 15 butir indicator yaitu: 1). Visi dan misi sekolah, 2). Rencana Kerja Jangka Menengah (RKJM) dan Rencana Kerja Tahunan (RKT), 3). Pedoman pngelolaan, 4). Struktur organisasi, 5). Program tahunan, 6). Kegiatan siswa, 7). Bidang kurikulum, 8). Tenaga pendidik dan kependidikan, 9). Penilaian pendidik dan kependidikan, 10). Pembiayaan, 11). Kemitraan, 12). Evaluasi kinerja sekolah, 13). Kepala sekolah, 14). Kinerja kepala sekolah, dan 15). Informasi manajemen. 
Hasil yang diperoleh disajikan dalam bentuk diagram dibawah ini:

Gambar A.1 Prosentase Pemahaman Guru

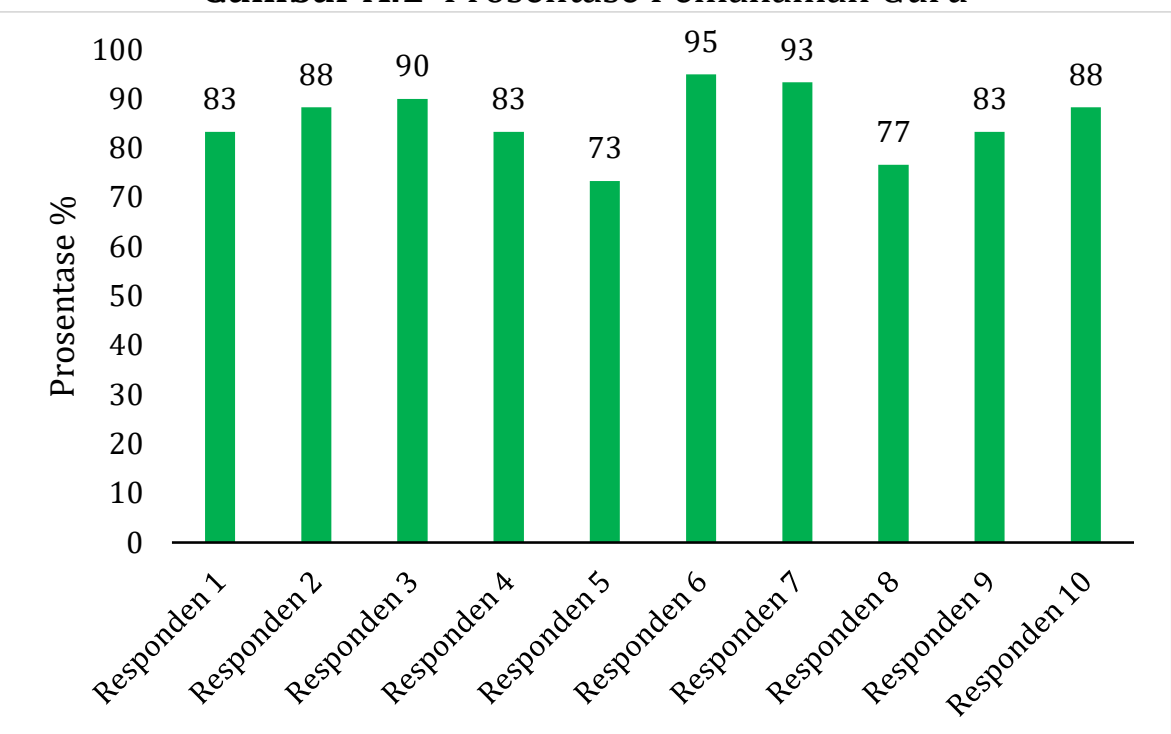

Gambar A.1 menunjukan bahwa pemahaman standar pengelolaan berdasarkan responden dari 10 guru dengan hasil yang bervariasi. Prosentase guru dengan angka diatas $90 \%$ terdapat 3 orang guru sedangkan prosentase guru dengan angka di bawah $80 \%$ ada 2 orang guru. Profil pemahan ini belum terlihat permasalahan yang spesifik perindikator dari standar pengelolaan pendidikan.

Selanjutnya disajikan mengenai pemahaman perindikator dalam bentuk diagram dibawah ini:

Gambar A.2 Prosentase Pencapaian setiap indokator

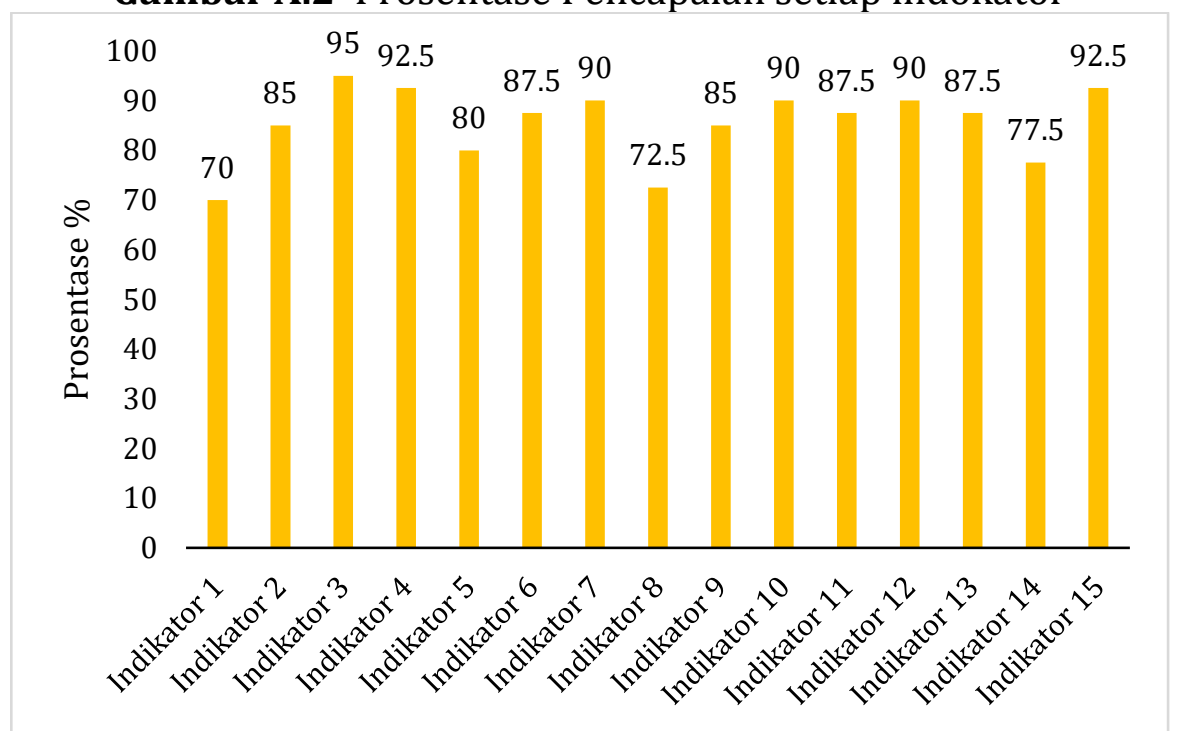

Gambar A.2 menunjukkan bahwa profil pemahaman standar pengelolaan berdasarkan indikator bervariasi. Guru dengan prosentase pemahaman terbesar terletak pada indicator $3,4,7,10,12$, dan 15. Indikator tersebut berkaitan dengan Pedoman pngelolaan, Struktur organisasi, Bidang kurikulum, Pembiayaan, Evaluasi kinerja sekolah dan Informasi manajemen. Sedangkan pencapaian indikator terendah yang kurang dari $80 \%$ terdapat pada indikator 1, 8 dan 14 mengenai Visi dan misi sekolah, mendayagunakan tenaga pendidik dan kependidikan, dan Kepala sekolah menerapkan prinsip-prinsip kepemimpinan pembelajaran dalam pengelolaan sekolah. 


\section{Problematika yang Dihadapi}

Problematika dalam pendidikan harus senantiasa dikaji untuk memberikan solusi terbaik. Problematika yang pertama mengenai prosentase guru dengan angka di bawah $80 \%$ ada 2 orang guru yaitu responden 5 dan responden 8 . Hasil pendalaman melalui wawancara diperoleh hasil yang menunjukan pemahaman masih rendah untuk responden 5 adalah indicator 4, 7 dan 13 (mengenai struktur organisasi, bidang kurikulum dan tugas dan fungsi Kepala sekolah). Sedangkan untuk responden 8 adalah indicator 2, 9, 11 dan 14. Mengenai Rencana Kerja Jangka Menengah (RKJM) dan Rencana Kerja Tahunan (RKT), Penilaian pendidik dan kependidikan, Kemitraan dan Kinerja kepala sekolah.

Permasalahan pemahaman pengelolaan pendidikan responden 5 adalah mengenai belum terlalu memahami struktur organisasi disekolah, disebabkan tidak terlibat aktif dalam structural dan mengajar didua tempat. Untuk bidang kurikulum memiliki pemahaman yang lemah disebabkan masih mengalami ketergantuangan kepada orang lain dalam hal perangkat pembelajaran. Dan masih lemah dalam memahami tugas dan fungsi Kepala sekolah disebabkan kurang inten mengikuti rapat dan kegiatan sekolah dan hanya aktif mengajar. Sedangkan responden 8 adalah masih mengalami kesulitan dalam memahami Mengenai Rencana Kerja Jangka Menengah (RKJM) dan Rencana Kerja Tahunan (RKT), penilaian pendidik dan kependidikan serta kemitraan dan kinerja kepala sekolah penyebabnya adalah merupakan guru baru dan masih dalam tahap pengenalan lingkungan sekolah lebih dalam.

Permasalahan selanjutnya mengenai pencapaian indikator terendah yang kurang dari $80 \%$ terdapat pada indikator 1, 8 dan 14 mengenai Visi dan misi sekolah, mendayagunakan tenaga pendidik dan kependidikan, dan Kepala sekolah menerapkan prinsip-prinsip kepemimpinan pembelajaran dalam pengelolaan sekolah. Hasil wawancara dari responden yang dengan kategori nilai tersebut diatas, hal yang menjadi kendala pada indicator visi dan misi sekolah adalah karena kurangnya sosialisi mengenai hal tersebut kepada guru dan juga visi misi dari setiap kepala sekolah bereda-beda yang menyebabkan beberapa guru merasa kebingungan. Visi misi merupakan ruh dalam sebuah kegiatan (Suryadi, 2012). Selanjutnya untuk indicator Tenaga pendidik dan kependidikan dan kemitraan dan kinerja kepala sekolah masih rendah disebabkan masih ada beberapa tenaga honorer yang tidak terlibat aktifnya langsung disekolah tersebut.

\section{Alternatif Solusi Permasalan Meneurut Pendidikan Islam}

Berikut alternative solusi dalam menghadapi permasalahan yang muncul yang disajikan dalam bentuk tabel.

Tabel A.1 Alternatif Solusi Permasalahan Peresponden

\begin{tabular}{|c|c|c|}
\hline No & Permasalahan & Alternatif Solusi \\
\hline 1 & $\begin{array}{l}\text { Responden 5, } \\
\text { belum } \\
\text { memahami } \\
\text { struktur } \\
\text { organisasi } \\
\text { disekolah, } \\
\text { disebabkan } \\
\text { tidak terlibat } \\
\text { aktif dalam } \\
\text { structural dan } \\
\text { mengajar di dua } \\
\text { tempat. }\end{array}$ & 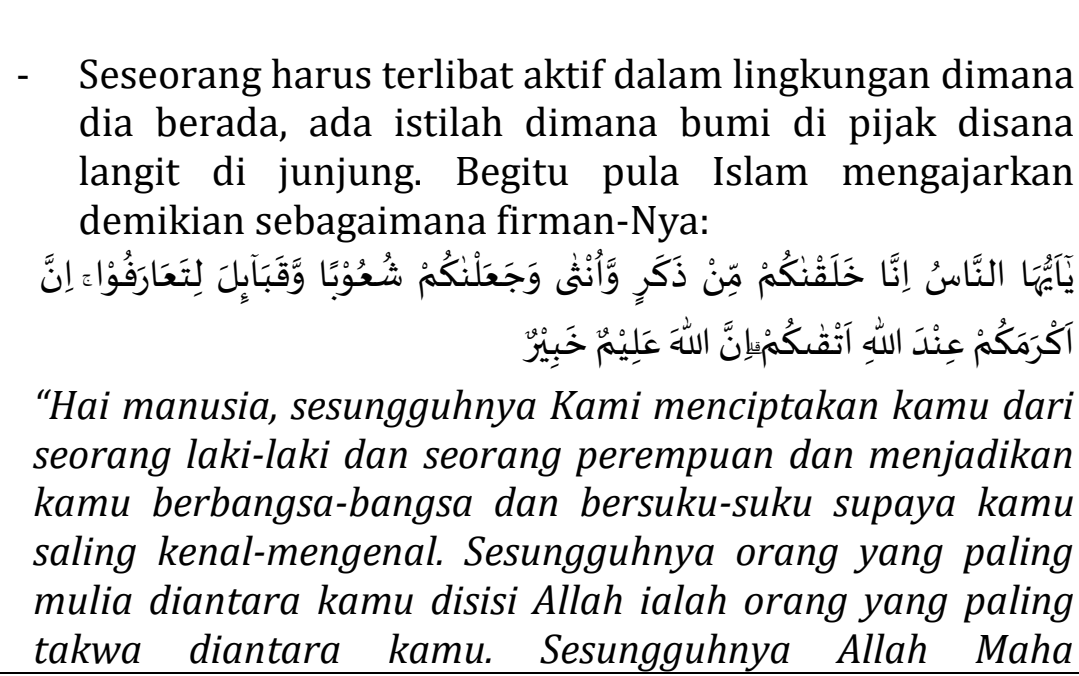 \\
\hline
\end{tabular}


Mengetahui lagi Maha Mengenal."

Saling mengenal dalam arti melaknasanakan dengan bersama-sama dalam mencapai tujuan. Semua pihak turut bertanggung jawab dalam hal pencapaian mutu pendidikan Islam (N. Amin, Siswanto, \& Hakim, 2018).

- Kurikulum dalam islam merupakan hal yang sangat urgent, karena marupakan parameter keberhasilan pendidikan (Mustaqim, 2014).

- Belum memahami kurikulum disebabkan masih mengalami ketergantuangan kepada orang lain dalam hal perangkat pembelajaran.

- Masih lemah dalam memahami tugas dan fungsi Kepala sekolah disebabkan kurang inten mengikuti rapat dan kegiatan sekolah
Allah berfirman:



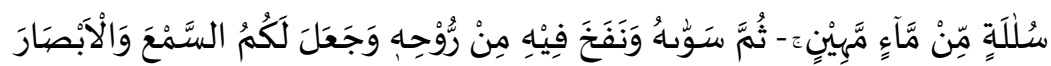

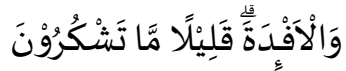

"Yang membuat segala sesuatu yang dia ciptakan sebaikbaiknya dan yang memulai penciptaan manusia dari tanah. Kemudian dia menjadikan keturunannya dari saripati air yang hina. Kemudian dia menyempurnakan dan meniupkan ke dalamnya roh (ciptaan)-Nya dan dia menjadikan bagi kamu pendengaran, penglihatan dan hati; (tetapi) kamu sedikit sekali bersyukur." (QS. As-Sajadah ayat $7-9$ ).

Dari ayat diatas diketahui bahwa segala sesuatu harus perencanaan, pelaksanaan dan evaluasi khusus untuk mencapai tujuan, begitu pula dengan pendidikan Islam (Yusuf, 2011).

- Dalam Islam mengikuti pemimpin yang baik adalah sebuah kewajiban. Sebagaimana firman Allah:

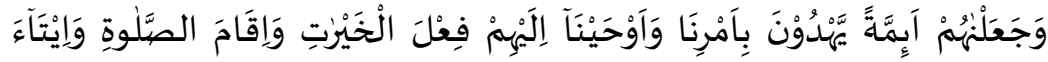



"Kami telah menjadikan mereka itu sebagai pemimpinpemimpin yang memberi petunjuk dengan perintah Kami dan telah Kami wahyukan kepada mereka mengerjakan kebajikan, mendirikan sembahyang, menunaikan zakat, dan hanya kepada Kamilah mereka selalu menyembah." (Al-Anbiya:73)

Ayat diatas merupakan diantara ayat yang menerangkan kriteria pemimpin yang bisa diikuti oleh orang yang dipimpinnya (S. Amin \& Siregar, 2015).

2 Responden 8, Masih mengalami kesulitan dalam memahami Mengenai (RKJM) dan (RKT), penilaian pendidik dan kependidikan serta kemitraan dan kinerja kepala
Solusi untuk responden 8 secara umum harus memahami terlebih dahulu lingkungan tempat kerja dengan baik. Sehingga mampu membaca situasi.

- Firman-Nya:

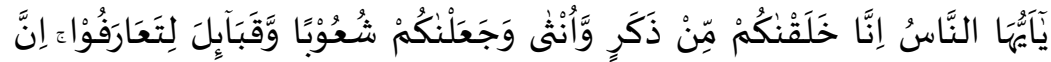

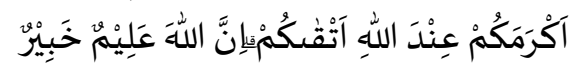

"Hai manusia, sesungguhnya Kami menciptakan kamu dari seorang laki-laki dan seorang perempuan dan menjadikan kamu berbangsa-bangsa dan bersuku-suku supaya kamu saling kenal-mengenal. Sesungguhnya orang yang paling 
sekolah

penyebabnya

adalah merupakan

guru baru dan

masih dalam tahap

pengenalan

lingkungan sekolah

lebih dalam. mulia diantara kamu disisi Allah ialah orang yang paling takwa diantara kamu. Sesungguhnya Allah Maha Mengetahui lagi Maha Mengenal."

Saling mengenal dalam arti melaknasanakan dengan bersama-sama dalam mencapai tujuan. Semua pihak turut bertanggung jawab dalam hal pencapaian mutu pendidikan Islam (N. Amin et al., 2018).

Selanjutnya alternative solusi dalam menghadapi permasalahan sesuai indikator yang terkendala dalam pemahamannya, berikut disajikan dalam bentuk tabel.

Tabel A.2 Alternatif solusi permasalahan Perindikator

\begin{tabular}{lll}
\hline No & Permasalahan & \multicolumn{2}{c}{ Alternatif Solusi } \\
\hline 1 & Pemahaman & Visi dan misi merupakan salah satu upaya dalam mencapai \\
& mengenai Visi dan & tujuan pendidikan Islam. Tujuan pendidikan Islam \\
& misi sekolah masih & orientasinya sukses dunia dan akhirat dengan menjalankan \\
& rendah & ibadah yang diperintahkan Tuhannya. Seperti dalam surat al \\
& & Dzariyat $(51) ; 56:$
\end{tabular}

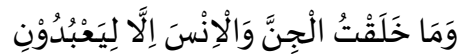

"Dan Aku menciptakan Jin dan Manusia kecuali supaya mereka beribadah kepada- Ku".

Aspek ibadah merupakan kewajiban orang Islam untuk mempelajarinya agar ia dapat mengamalkannya dengan cara yang benar (Trinurmi, 2015). Pendidikan Islam sangat relevan karena tujuan dan hakekat pendidikan Islam adalah mewujudkan manusia paripurna (Insan Kamil) yang dicintai oleh Allah swt (Abuddin Nata, 2001). Visi misi perlu disosialisasikan, dilaksanakan dan dievaluasi untuk mengukur ketercapaiannya.

2 Pemahaman Pentingnya kompetensi dalam suatu pekerjaan dinyatakan mengenai mendayagunakan tenaga pendidik dan kependidikan masih rendah Rasulullah saw dalam sabdanya sebagai berikut:

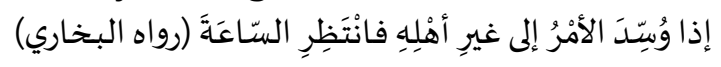

"Apabila suatu pekerjaan diserahkan kepada orang yang bukan ahlinya, maka tunggulah kehancuran." (HR. Bukhari)

Dalam hal ini pendidik ataupun tenaga kependidikan harus memiliki kompetensi yang mumpuni (Suraji, 2012).

3 Pemahaman mengenai Kepala sekolah Pemimpin itu harus mampu mempengaruhi, mendorong mengajak untuk mencapai tujuan yang diharapkan (Nurhayati, 2016). Sebagaimana firman Allah:

menerapkan prinsip-prinsip kepemimpinan pembelajaran dalam pengelolaan sekolah.

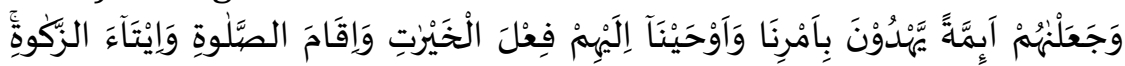

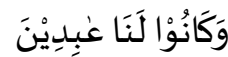

"Kami telah menjadikan mereka itu sebagai pemimpinpemimpin yang memberi petunjuk dengan perintah Kami dan telah Kami wahyukan kepada mereka mengerjakan kebajikan, mendirikan sembahyang, menunaikan zakat, dan hanya kepada Kamilah mereka selalu menyembah." (Al-Anbiya:73)

Ayat diatas merupakan diantara ayat yang menerangkan kriteria pemimpin yang bias di ikuti oleh orang yang dipimpinnya (S. Amin \& Siregar, 2015). 


\section{Pengelolaan dalam mencapai tujuan pendidikan Islam}

Pendidikan dipandang sebagai sekumpulan pewaris kebudayaan dan pengembang potensi-potensi. Pendidikan Islam adalah suatu proses yang berlangsung continue/ berkesinambungan. Maka tugas dan fungsi yang diemban oleh pendidikan Islam adalah pendidikan manusia seutuhnya dan berlangsung sepanjang hayat (Mustaghfiroh, 2015). Konsep ini bermakna bahwa tugas dan fungsi pendidikan memiliki sasaran pada peserta didik yang senantiasa tumbuh berkembang secara dinamis, mulai dari kandungan sampai meninggal dunia. Termasuk pendidikan islam senantiasa relevan dengan kemajuan teknologi agar mampu bersaing dengan lembaga umum lainnya (Chairunnisa, Najiyah, Salsabila, \& Dikara, 2020).

Hal pokok dalam Pendidikan Islam adalah aspek tujuan (Rahman, 2012). Merumuskan tujuan pendidikan merupakan syarat mutlak dalam mendefiniskan pendidikan itu sendiri yang paling tidak didasarkan atas konsep dasar mengenai manusia, alam, dan ilmu serta dengan pertimbangan prinsip prinsip dasarnya. Al-Ghozali menyebutkan bahwa tujuan pendidikan sesuai dengan pandangan hidup manusia yakni memberi petunjuk akhlak dan pembersihan jiwa yang tertandai dengan sifat-sifat takwa (Hasbiyallah \& Sulhan, 2013).

Dalam konsep dasar filosofis pendidikan Islam lebih mendalam dan menyangkut persoalan hidup multi-dimensional, yaitu pendidikan yang tidak terpisahkan dari tugas kekhalifahan manusia, atau lebih khususnya sebagai sarana untuk memperispakan kaderkader khalifah di bumi. Dengan tujuan membangun kehidupan yang makmur, dinamis, harmonis dan lestari sesuai syariat Allah dalam al Qur'an. Konsep pendidikan Islam di Indonesia harus senantiasa sejalan dengan tujuan pancasila, dan islam sangat melarang keras tidakan intoleran, tindakan persekusi, namun islam mengedepankan urgensi pendidikan multicultural (Muthohirin, 2019).

Pendidikan Islam adalah pendidikan yang ideal, sebab visi dan misinya adalah "Rahmatan Lil 'Alamin", yaitu untuk membangun kehidupan dunia yang makmur, demokratis, adil, damai, taat hukum, dinamis, dan harmonis. Munzir Hitami berpendapat bahwa tujuan pendidikan tidak terlepas dari tujuan hidup manusia. Bila dilihat dari ayatayat al Qur'an ataupun hadits terdapat beberapa macam tujuan, termasuk tujuan yang bersifat teologis (A. Nata, 2016).

Menurut Al Syaibani dalam (Rizal, 2014), tujuan pendidikan Islam adalah 1). Tujuan individu, 2). Tujuan masyarakat dan 3). Tujuan professional. Pemahaman sederhananya bahwa tujuan pendidikan Islam mengandung tiga hal yaitu berkaitan dengan masalah individu, masyarakat dan pofesionalisme. Tiga hal tersebut terpenuhi, maka akan tercapai tujuan pendidikan Islam yang efektif dan efisien. Dalam mencapai hal tesebut maka diperlukanlah pengelolaan pedidikan yang baik atau management yang baik. Mulai dari konsep yang baik, perencanaan yang baik, tindakan yang baik serta evaluasi yang baik maka tujuan pendidikan Islam akan tercapai.

Istilah management diterjemahkan ke dalam Bahasa Indonesia menjadi manajemen atau pengelolaan. Manajemen sendiri, dalam Kamus Bahasa Indonesia, diartikan sebagai proses pemakaian sumber daya secara efektif untuk mencapai tujuan. Menurut Parker, manajemen ialah seni dalam menjalankan program. Adapun pengertian manajemen dalam arti luas adalah perencanaan, pengorganisasian, pengarahan dan pengendalian (P4) sumber daya organisasi untuk mencapai tujuan secara efektif dan efisien (Suhartini, 2015). Ramayulis menyatakan bahwa pengertian yang sama dengan hakikat manajemen adalah al-tadbir (pengaturan). Kata ini merupakan derivasi dari kata dabbara (mengatur) yang banyak terdapat dalam Alquran seperti firman Allah Swt.: 


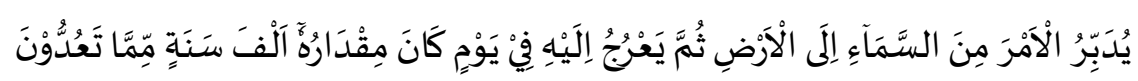

Artinya: "Dia mengatur urusan dari langit ke bumi, kemudian (urusan) itu naik kepadanya dalam satu hari yang kadarnya adalah seribu tahun menurut perhitunganmu" (QS. AsSajdah/32: 5).

Ayat di atas menyatakan bahwa Allah adalah Sang Pengatur alam atau Sang Manager. Kemudian dilimpahkan tugas tersebut kepada manusia. Maka dari itu manusia harus mengatur dan mengelola bumi dengan sebaik-baiknya sebagaimana Allah mengatur alam raya ini. Istilah manajemen sebenarnya mengacu kepada proses pelaksanaan aktifiitas yang pendayagunaan orang lain (Achyar, 2019). Dengan adanya kepala sekolah dalam dunia pendidikan, maka diharapkan memiliki karakter kepemimpinan, terampil dan dan cakap bisa bekerjasama dengan bawahannya untuk menjadikan lembaga yang dipimpinya lebih berkembang dan manju (Chairunnisa et al., 2020).

Terry memberikan defenisi: "management is a distinct process consisting of planning, organizing, actuating and controlling, performed to determine and accomplish stated objectives by the use of human beings and other resources". Maksudnya manajemen sebagai suatu proses yang jelas terdiri dari tindakan-tindakan perencanaan, pengorganisasian, pelaksanaan, dan pengendalian yang dilaksanakan untuk mencapai tujuan yang telah ditentukan (Hidayat \& Machali, 2012). Begitupun dengan pendapat Ema Chairunnisa, bahwa kepemimpinan adalah kunci penting dalam melakukan pembinaan, bimbingan, dan memberikan arahan kepada jajaran struktur di bawahnya untuk menjalankan fungsi koordinasi dan instruksi sehingga bisa bergerak sesuai dengan pekerjaannya masingmasing dan mencapai tujuan bersama (Chairunnisa et al., 2020)

Lebih lanjut Mujammil Mengatakan manajemen pendidikan Islam memiliki implikasi-implikasi antara lain 1). Proses pengelolaan lembaga pendidikan Islam harus Islami, 2). Terarah kepada lembaga pendidikan Islam, 3). Proses pengelolaan lembaga menghendaki adanya sifat inklusif dan eksklusif 4). Dengan memakai strategi untuk mencapai tujuan, 5). Meliputi unsur-unsur yang komplek, 6). Tujuan pendidikan Islam dan 7). Pelaksanaan yang bersifat efektif dan efisien (Syihabuddin, 2019).

Manajemen pendidikan Islam prinsipnya umum dan fleksibel yang sejalan dengan kemajuan dan perkembangan zaman. Ramayulis berpendapat bahwa prinsip manajemen pendidikan Islam ada delapan yaitu: ikhlas, jujur, amanah, adil, tanggung jawab, dinamis, praktis, dan fleksibel (Achyar, 2019). Sedangkan Langgulung berpendapat bahwa prinsip manajemen pendidikan Islam ada tujuh, yaitu: iman dan akhlak, keadilan dan persamaan, musyawarah, pembagian kerja dan tugas, berpegang pada fungsi manajemen, pergaulan dan keiklasan. Serta Islam melarang dan menghindari hal-hal yang menjerumuskan kedalam rasisme dan xenophobia (Abadi \& Muthohirin, 2020).

Dengan demikian pengelolaan pendidikan adalah salah satu upaya dalam mencapai tujuan umum pendidikan Islam. Dimana tujuan pendidikan Islam orientasinya sukses dunia dan akhirat dengan menjalankan ibadah yang diperintahkan Tuhannya. Seperti dalam surat al Dzariyat (51) ; 56 :

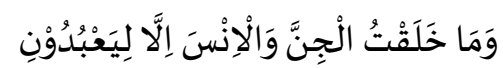

"Dan Aku menciptakan Jin dan Manusia kecuali supaya mereka beribadah kepada- Ku".

Ibadah itu tidak terbatas pada menunaikan shalat, shaum pada bulan Ramadhan, mengeluarkan zakat, ibadah Haji, serta mengucapkan syahadat. Tetapi sebenarnya ibadah itu mencakup semua amal, pikiran, dan perasaan yang dihadapkan (atau disandarkan) kepada Allah. Aspek ibadah merupakan kewajiban orang Islam untuk mempelajarinya agar dapat mengamalkannya dengan cara yang benar. Ibadah ialah jalan hidup yang mencakup seluruh aspek kehidupan serta segala yang dilakukan manusia berupa perkataan, perbuatan, perasaan, pemikiran yang disangkutkan dengan Allah (Trinurmi, 2015). 
Palahudin, dkk.: Implementasi Standar Pengelolaan Pendidikan

Pendidikan Islam sangat relevan karena tujuan dan hakekat pendidikan Islam adalah mewujudkan manusia paripurna (Insan Kamil) yang dicintai oleh Allah swt (D. R. H. A. Nata, 2014).

\section{KESIMPULAN}

Pengelolaan pendidikan yang sinergi antara pimpinan dengan yang dipimpin, tertata dengan baik, mengedepankan asas iman dan akhlak, keadilan dan persamaan, musyawarah, pembagian kerja dan tugas, berpegang pada fungsi manajemen, pergaulan dan keiklasan. Maka tujuan pendidikan Islam akan tercapai dengan efektif dan efisien. Dalam hal ini, manajemen pendidikan Islam perlu titik tekan pada kerja-kerja internalisasi, aktualisasi dan implementasi nilai-nilai kemanusiaan yang dipadukan dengan muatan pesan-pesan Al-Qur'an (Abadi \& Muthohirin, 2020). Pola pengelolaan yang seperti ini kontekstual mengingat banyak dijumpai berbagai tindak kekerasan di dunia nyata dan ragam narasi kebencian bernadakan agama di media sosial (Muthohirin, 2019).

Sementara itu, tujuan pendidikan Islam haruslah sejalan dengan pandangan hidup manusia. Yakni memberi petunjuk akhlak dan pembersihan jiwa untuk mencapai drazat takwa. Hakekat dan tujuan hidup manusia yang dihubungkan dengan hakekat dan tujuan pendidikan Islam adalah mendidik individu yang saleh dengan memperhatikan perkembangan rohaniah, emosional, sosial, intelektual dan fisik, mendidik anggota kelompok sosial yang saleh, baik dalam keluarga maupun masyarakat muslim.

\section{DAFTAR PUSTAKA}

Abadi, M., \& Muthohirin, N. (2020). Metode Cultural Responsive Teaching dalam Pendidikan Agama Islam: Studi Kasus Tindak Xenophobia dan Rasisme di Tengah Bencana Covid-19. Progresiva: Jurnal Pemikiran Dan Pendidikan Islam, 9(1), 34-48.

Achyar, A. (2019). Konsep Manajemen Mutu Terpadu Dan Implementasinya Dalam Pendidikan Islam Studi Kasus Di Pondok Pesantren Darul Muttaqien Bogor. Tawazun: Jurnal Pendidikan Islam, 10(2), 193-218.

Amin, N., Siswanto, F., \& Hakim, L. (2018). Membangun Budaya Mutu yang Unggul Dalam Organisasi lembaga Pendidikan Islam. Al-Tanzim: Jurnal Manajemen Pendidikan Islam, 2(1), 94-106.

Amin, S., \& Siregar, F. M. (2015). Pemimpin dan Kepemimpinan dalam al-Qur'an. Tanzil: Jurnal Studi Al-Qur'an, 1(1), 27.

Anwar, H. (2017). Standar Pengelolaan Pendidikan Dalam Perspektif Pengelolaaan Madrasah Aliyah Swasta. Tadbir: Jurnal Manajemen Pendidikan Islam, 5(2), 15-27.

Chairunnisa, E., Najiyah, C., Salsabila, H., \& Dikara, W. N. C. (2020). Kepemimpinan Bermutu: Konsep Pengembangan Lembaga Pendidikan Islam. Progresiva: Jurnal Pemikiran Dan Pendidikan Islam, 9(1), 26-33.

Hasbiyallah, H., \& Sulhan, M. (2013). Hadis Tarbawi dan hadits-hadits di sekolah dan madrasah.

Hidayat, A., \& Machali, I. (2012). Pengelolaan pendidikan: Konsep, prinsip, dan aplikasi dalam mengelola sekolah dan madrasah. Kaukaba.

Ikhwan, A. (2016). Manajemen Perencanaan Pendidikan Islam (Kajian Tematik Al-Qurâ€TM an dan Hadist). Edukasi: Jurnal Pendidikan Islam, 4(1), 128-155.

Jannah, M. (2020). Partisipasi Orang Tua Dalam Meningkatkan Kualitas Pendidikan Dasar Anak. Universitas Negeri Semarang.

Maqfirah. (2013). Efektivitas Pengelolaan Administrasi Akademik Fakultas Syariah IAIN Ar-Raniry Banda Aceh. Jurnal Mudarrisuna, 3(2), 328-349. http://dx.doi.org/10.22373/jm.v3i2.274 
Mustaghfiroh, H. (2015). Rekonstruksi Filsafat Pendidikan Islam (Mengembalikan Tujuan Pendidikan Islam Berbasis Tujuan Penciptaan Dan Tujuan Risalah). Edukasia: Jurnal Penelitian Pendidikan Islam, 10(1).

Mustaqim, Y. (2014). Pengembangan Konsepsi Kurikulum dalam Pendidikan Islam. Edukasia: Jurnal Penelitian Pendidikan Islam, 9(1).

Muthohirin, N. (2019). Politik Identitas Islam dan Urgensi Pendidikan Multikultural. J-PAI: Jurnal Pendidikan Agama Islam, 6(1).

MUTIA. (2019). Pelaksanaan Standar Pengelolaan Pendidikan Di Madrasah Tsanawiyah $\begin{array}{lllll}\text { Negeri } & 2 & \text { Bandar } & \text { Lampung }\end{array}$ https://doi.org/10.1017/CB09781107415324.004

Nata, A. (2016). Islam Rahmatan lil Alamin Sebagai Model Pendidikan Islam Memasuki Asean Community. Makalah Disampaikan Pada Acara "Kuliah Tamu" Jurusan Pendidikan Agama Islam Fakultas Ilmu Tarbiyah Dan Keguruan UIN Maulana Malik Ibrahim Malang Senin, 7.

Nata, D. R. H. A. (2014). Perspektif Islam tentang strategi pembelajaran. Kencana.

Nurhayati, T. (2016). Hubungan Kepemimpinan Transformasional dan Motivasi Kerja. Edueksos: Jurnal Pendidikan Sosial \& Ekonomi, 1(2).

Rahayu, M. (2015). Pelaksanaan Standar Pengelolaan Pendidikan Di Sekolah Dasar Kecamatan Ngemplak Kabupaten Sleman. Jurnal Penelitian Ilmu Pendidikan, 8(1), 62-79. https://doi.org/10.21831/jpipfip.v8i1.4929

Rahman, A. (2012). Pendidikan Agama Islam dan Pendidikan Islam-Tinjauan Epistemologi dan Isi-Materi.". Jurnal Eksis, 8(1), 2053-2059.

Rizal, A. S. (2014). Perumusan Tujuan Sebagai Basis Pengembangan Kurikulum Pendidikan Islam. Jurnal Pendidikan Agama Islam-Ta'lim, 12(2), 97-112.

Rohman, A. N. (2019). Pengaruh model pembelajaran Role Playing terhadap partisipasi siswa pada mata pelajaran pendidikan agama Islam: Penelitian pada siswa kelas XI SMA Negeri 1 Kasokandel Kecamatan Kasokandel Kabupaten Majalengka. Universitas Islam Negeri Sunan Gunung Djati Bandung.

Sekolah, B. A. (n.d.). Madrasah. Muti, A (2017). Perangkat Akreditasi Sekolah SMP/MTs.

Soendari, T. (2012). Metode Penelitian Deskriptif. Online) Https://Academia. Edu/JurnalMetode-Penelitian-Deskriptifpdf. Html (Diakses 15 Juni 2017).

Suhartini, Y. (2015). Analisis terhadap managemen program pendidikan agama islam bagi narapidana di lembaga pemasyarakatan klasifikasi I sukamiskin Bandung.

Suraji, I. (2012). Urgensi Kompetensi Guru. Edukasia Islamika, 10(2), 70284.

Suryadi, D. (2012). Pentingnya Visi Dan Misi Dalam Mengelola Suatu Usaha. Asy-Syukriyyah, 9(1), 17-35.

Syihabuddin, M. A. (2019). Landasan Manajemen Pendidikan Islam. Cendekia, 11(1), 39-50.

Trinurmi, S. (2015). Hakekat dan Tujuan Hidup Manusia dan Hubungannya dengan Tujuan Pendidikan Islam. Al-Irsyad Al-Nafs: Jurnal Bimbingan Dan Penyuluhan Islam, 2(1).

Wardani, K. W., Loekmono, L., \& Supramono, S. (2017). Keterlaksanaan Standar Pengelolaan Pendidikan Di Sma Terakreditasi. Kelola: Jurnal Manajemen Pendidikan, 4(1), 12. https://doi.org/10.24246/j.jk.2017.v4.i1.p12-27

Widoyoko, E. P. (2009). Evaluasi program pembelajaran. Yogyakarta: Pustaka Pelajar, 238.

Yusuf, N. (2011). Perspektif Islam tentang Pengintegrasian Ilmu Akhlak dalam Pembelajaran Ilmu Sains dan Penerapannya di Lembaga Pendidikan Islam. Kutubkhanah, 14(2), 233-242. 